\title{
COVID-19: Spatial Dynamics and Diffusion Factors across Russian Regions
}

\author{
S. P. Zemtsov ${ }^{a, b}, *$ and V. L. Baburin ${ }^{b, c, * *}$ \\ ${ }^{a}$ Russian Presidential Academy of National Economy and Public Administration, Moscow, 119571 Russia \\ ${ }^{b}$ Faculty of Geography, Lomonosov Moscow State University, Moscow 119991 Russia \\ ${ }^{c}$ Kant Baltic Federal University, Kaliningrad, 236041 Russia \\ *e-mail: spzemtsov@gmail.com \\ **e-mail: vbaburin@yandex.ru
}

Received April 20, 2020; revised May 12, 2020; accepted May 12, 2020

\begin{abstract}
The observed spread of coronavirus infection across Russian regions, as a first approximation, obeys the classic laws of diffusion of innovations. The article describes in detail theoretical approaches to the analysis of the spread of social diseases and discusses methodological limitations that reduce the possibility of predicting such phenomena and affect decision-making by the authorities. At the same time, we believe that for most regions, including Moscow, until May 12, 2020, the dynamics of confirmed cases are a reduced and delayed reflection of actual processes. Thus, the introduced self-isolation regime in Moscow and other agglomerations affected the decrease in the number of newly confirmed cases two weeks after its introduction. In accordance with our model, at the first stage, carriers infected abroad were concentrated in regions with large agglomerations and in coastal and border areas with a high intensity of internal and external links. Unfortunately, the infection could not be contained, and it started growing exponentially across the country. By mid-April 2020, cases of the disease were observed in all Russian regions; however, the remotest regions least connected with other parts of Russia and other countries had only isolated cases. By mid-May, at least in Moscow, the number of new cases began to decline, which created the prerequisites for reducing restrictions on the movement of residents. However, the decrease in the number of new cases after passing the peak of the epidemic in May is slower than the increase at the beginning. These facts contradict the diffusion model; thus, the model is not applicable for epidemiological forecasts based on empirical data. Using econometric methods, it is shown that for different periods of diffusion, various characteristics of the regions affect the spread of the disease. Among these features we note the high population density in cities, proximity to the largest metropolitan areas, higher proportion of the most active and frequently traveling part of the population (innovators, migrants), and intensive ties within the community, as well as with other regions and countries. The virus has spread faster in regions where the population has a higher susceptibility to diseases, which confirms the importance of the region's health capital. The initial stage was dominated by random factors. We conclude this paper with directions for further research.
\end{abstract}

Keywords: diffusion of innovations, COVID-19, regional factors, health capital, population density, social contacts, anti-contagion policy

DOI: $10.1134 / \mathrm{S} 2079970520030156$

\section{INTRODUCTION}

Recent decades, in Russia and abroad, have been marked by the increasing frequency of natural hazards, ${ }^{1}$ including epidemics. However, the COVID-19 pandemic is distinguished by its global scale, the unprecedented actions undertaken by the authorities, and the public's response. We performed our calculations in the initial stages of the epidemic. As of midMay 2020, there were more than $4.5 \mathrm{mln}$ confirmed

\footnotetext{
${ }^{1}$ IPCC Fifth Assessment Report (AR5) (2014): https:// www.ipcc.ch/assessment-report/ar5/. Accessed May 11, 2020.
}

cases of infection globally, including more than $1.56 \mathrm{mln}$ cases, where the patients have recovered, and 0.29 mln fatal cases. ${ }^{2}$ As of May 12, 2020, Russia had more than 230000 confirmed cases of the SARSCoV-2 coronavirus infection, including about 43000 people who were discharged from hospitals and more than 2100 deaths. $^{3}$

\footnotetext{
${ }^{2}$ Coronavirus statistics today (2020): https://koronavirusncov.ru/. Accessed May 12, 2020.

${ }^{3}$ Rospotrebnadzor Russia (2020). News about the coronavirus: https://rospotrebnadzor.ru/about/info/news/. Accessed May 12, 2020.
} 
According to new data after the article was accepted for publication as of October 5, 2020, 1225889 cases of coronavirus infection were registered in Russia (35.4 mln in the world), 982324 people (80.1\%) were discharged for recovery. 21475 patients with coronavirus died in Russia (1.75\%), $1.036 \mathrm{mln}$ died in the world $(2.95 \%){ }^{4}$

We can identify several global trends that determine the growing vulnerability of the population against various diseases: the climate change and the related invasive spread of infections and parasites; the growing population density (urbanization) and mobility, which lead to the rapid spread of diseases; population aging and environmental degradation, which result in lower health (immunity) and higher susceptibility to diseases. Therefore, it is reasonable to believe that the number of future local outbreaks and epidemics will increase.

In our opinion, the geography of the distribution of confirmed cases of the disease is characterized by the classic factors of the diffusion of innovations, where the diffusion is affected by the structure of local communities in terms of their population density, connections, social activity, income, etc. Therefore, we find it relevant to apply the corresponding models of spatial diffusion [1,2] with certain limitations, discussed in detail in the methodological part. In this work, the application of the diffusion model is not aimed at studying new technologies post-factum but at identifying factors and scenarios related to the spread of the disease. The hypothesis of our study is that the spatial distribution of COVID-19 in Russia can be correctly modeled using diffusion models of social innovations, where deviations from the standard model are determined by random factors, limited statistical data, validity of quarantine and other (testing) measures undertaken by the authorities, and society's response to these measures. In regions with a small number of identified cases, the stochastic component and subjective factors can lead to significant deviations from the model. However, as the virus spreads in the regions, the importance of random factors decreases, and the effect of the authorities actions grows.

The aim of this study is to describe the geography and dynamics of the spread of confirmed (registered) cases of COVID-19 in Russia using the model of the diffusion of innovations and to estimate the possible factors affecting this process in the regions.

\section{OVERVIEW OF DIFFUSION MODELS WITH RESPECT TO SOCIAL DISEASES}

The diffusion of innovations is a process of spreading new phenomena in a community through various

\footnotetext{
${ }^{4}$ Rospotrebnadzor Russia (2020). News about the coronavirus: https://rospotrebnadzor.ru/about/info/news/. Accessed October 5, 2020.
}

communication channels [27]. Traditionally, the distribution of innovations in communities was studied by sociologists [27], economists [15, 18], and geographers [20], who had gained extensive experience in terms of modeling social changes (revolutions, new institutions, laws, etc.), introduction of new technologies (Internet, mobile communications, etc.), development of new products and services (computers, smartphones, Internet banking, etc.), and dissemination of information (advertising, propaganda, etc.) ${ }^{5}$. Some works discuss the modeling of social diseases, such as HIV/AIDS [16], which not only spread from one carrier to another by the principle of infection (neighborhood) but also account for the structure of communities. As we show below, COVID-19 can also be related to this type of disease in the early stages of its spread.

According to the classic works [20, 27], which remain relevant, innovations, including social diseases, spread in the community in its ascending part (up to the saturation point $\alpha$ ) following the logistic curve in cumulative form (the $S$-shaped light curve in Fig. 1a, the proportion of those infected at certain points in time) and obeys the normal distribution law for new infections (the bell-shaped dark curve) [1].

In terms of the time of the spread of the disease since the first confirmed case in the community, several groups in the population can be distinguished [27] (the $\mathrm{X}$ axis in Fig. 1a; Table 1), which differ in their ability to contract the disease (age) and transmit it, primarily, based on their social activity: innovators (1), early adopters (2), early majority (3), late majority (4), and laggards (5).

Innovators are active and open members of the community, prone to moving outside the country. In Russia, these are often young people, students, representatives of creative professions, athletes, programmers, etc. Since they often visit other countries, regardless of the size of their income, they could contribute to the spread of the virus in the initial stages. Note that in terms of the diffusion of the disease, this category can also include individual foreign workers from countries-centers of infection, as well as representatives of professions involved in transport services, tourism, and other areas of activity related to international contacts.

Early adopters are most often middle-aged people with a high income and social status, such as politicians, top managers, senior officials, famous scientists, doctors, popular representatives of creative professions (actors, directors, musicians, writers, etc.), and others. They actively participate in various public events, visit foreign countries, including for business trips. Due to their status, they are able to ignore the demands of the government. The early adopters themselves are able to exert pressure on the federal and

\footnotetext{
${ }^{5}$ See detailed review in [2].
} 
(a)

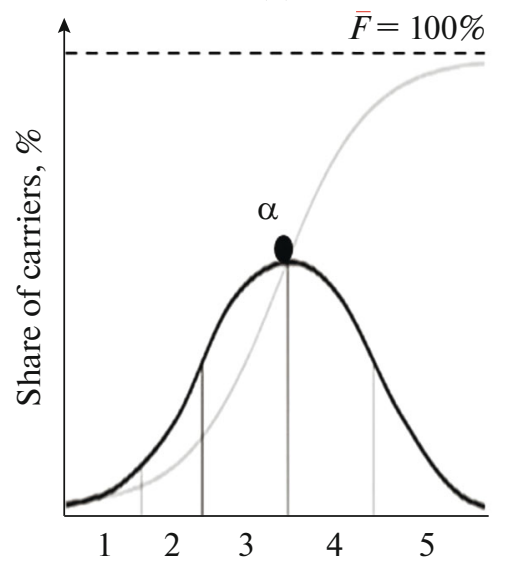

(b)

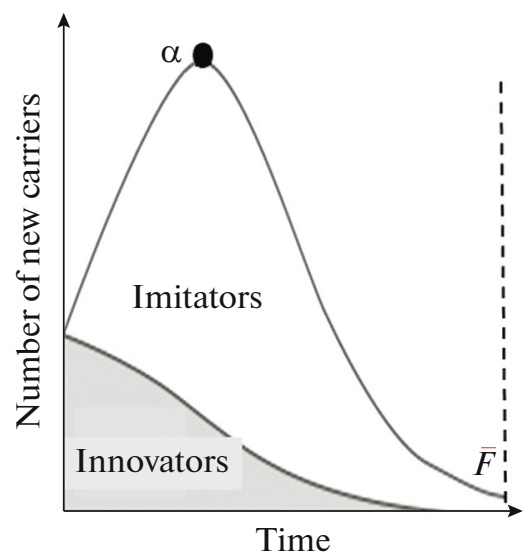

(c)

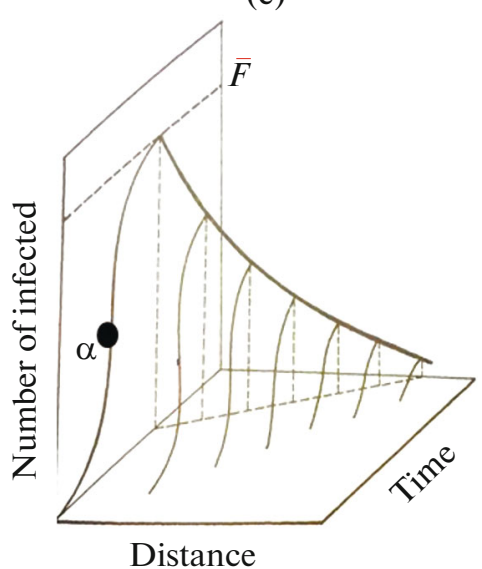

Fig. 1. (a) Share of infected members of community: light curve, cumulative number; dark curve, new carriers [27]. (b) Ratio of innovators and imitators among new carriers [15]. (c) Dependence of cumulative number of carriers on time and distance to source of infection [25].

regional authorities with regard to taking certain measures. They are able to infect the largest number of people in the initial stages of distribution, as they represent the center of social networks.

The spread of the disease can be stopped, primarily, by isolating the innovators and early adopters; however, this is the most challenging task. Note that the capacities of healthcare systems around the world are not designed to cope with even innovators alone; for example, the number of beds does not cover more than $1.5 \%$ of the population in the leading country in terms of this indicator, Japan, and the number of beds for infected patients is even less. ${ }^{6}$ Therefore, complete hospitalization of confirmed infected people is not possible in most countries; accordingly, government measures are limited to recommendations for quarantine and self-isolation, which may be ineffective for the reasons given above.

Various forms of personal contact represent an important factor in the spread of infectious diseases. After innovators and early adopters became infected abroad, they carried over the infection to their communities (often without knowing that they were infected $^{7}$ ). The higher the number of potential carriers of infection the higher its spread rate and the greater the number of new carriers. This process accelerates exponentially until the number of infected members of society reaches half of the maximum possible (the inflection point $\alpha$ of the $S$-shaped curve in Fig. 1). After this, the trend reverses direction.

\footnotetext{
${ }^{6}$ OECD Health Care Resources (2019): https://data.oecd.org/ healtheqt/hospital-beds.htm. Accessed May 11, 2020.

${ }^{7}$ The coronavirus infection, in contrast to classic diffusion, has a prolonged period when carriers are unaware of their illness and do not show external signs, which accelerates the spread when quarantine measures are not complied with.
}

F. Bass [15] divided community representatives into two groups depending on the model of the spread of innovations (Fig. 1b, formula (1)). The first group includes innovators who have adopted the innovation without interacting with members of their community. In our case, we are talking about the first confirmed infected people who visited the foci of the disease abroad (China, Italy). The second group consists of imitators, who have adopted the innovation after personal contact with the innovators; i.e., they were infected in Russia. Thus, the probability of getting infected with coronavirus at time $t$ can be determined by the linear dependence on the number of virus carriers in the community:

$$
P(t)=p+q / F(t)
$$

where $p$ is the coefficient of primary infection or the proportion of innovators, $q$ is the coefficient of imitation or the percentage of those infected from primary carriers, and $F(t)$ is the proportion of infection carriers at time $t$. In this case, the probability function is a distribution close to normal (Fig. 1b). Having calculated the derivative, we obtain the probability density function for a newly infected patient at time $t(f(t))$ :

$$
f(t)=d F(t)) / d t=\left[p+\frac{q}{F} F(t)\right][\bar{F}-F(t)],
$$

where $\bar{F}$ is the maximum potential number of cases.

The development of the discussed approach resulted in new models [25] that may be applicable to the analysis of the spread of diseases. For example, spatial models describe the characteristics of the spread of the virus depending on the proximity of the source of infection (China or Moscow) (Fig. 1c): the source itself is characterized by the maximum number of infected people and the highest rate of spread, near the source these parameters are reduced, and at the 
Table 1. Characteristics of groups of people according to their susceptibility to disease (adoption of innovation, in classic works)

\begin{tabular}{l|l|l|l|l|l|l|l}
\hline \multicolumn{1}{c|}{ Group } & Age & Income & $\begin{array}{l}\text { Ability } \\
\text { to endure } \\
\text { the disease } \\
\text { without } \\
\text { complications }\end{array}$ & $\begin{array}{l}\text { Social } \\
\text { status }\end{array}$ & Education & $\begin{array}{l}\text { Decision-making } \\
\text { behavior }\end{array}$ & $\begin{array}{l}\text { Contact } \\
\text { with environment }\end{array}$ \\
\hline $\begin{array}{l}\text { Innovators } \\
(1 \text { in Fig. 1a; } \\
\approx 2.5 \%)\end{array}$ & Young & Varies & High & Varies & $\begin{array}{l}\text { Secondary } \\
\text { and higher }\end{array}$ & $\begin{array}{l}\text { Risky, less likely } \\
\text { to comply with } \\
\text { rules }\end{array}$ & Frequent travel \\
\hline $\begin{array}{l}\text { Early adopters } \\
(2 ; \approx 13.5 \%)\end{array}$ & Medium & High & Medium high & $\begin{array}{l}\text { Social } \\
\text { leaders }\end{array}$ & Higher & $\begin{array}{l}\text { Less risky, } \\
\text { pragmatic }\end{array}$ & $\begin{array}{l}\text { Frequent } \\
\text { business trips }\end{array}$ \\
\hline $\begin{array}{l}\text { Early majority } \\
(3 ; \approx 34 \%)\end{array}$ & Medium & $\begin{array}{l}\text { Middle } \\
\text { class }\end{array}$ & Medium & $\begin{array}{l}\text { High and } \\
\text { medium }\end{array}$ & Higher & Pragmatic & $\begin{array}{l}\text { Actively attend } \\
\text { events }\end{array}$ \\
\hline $\begin{array}{l}\text { Late majority } \\
(4 ; \approx 34 \%)\end{array}$ & Senior & $\begin{array}{l}\text { Below } \\
\text { medium }\end{array}$ & Medium & $\begin{array}{l}\text { Medium } \\
\text { and low }\end{array}$ & Secondary & $\begin{array}{l}\text { Conservative, } \\
\text { skeptics }\end{array}$ & Less active \\
\hline $\begin{array}{l}\text { Laggards } \\
(5 ; \approx 16 \%)\end{array}$ & Senior & Low & Medium low & Low & Basic & Traditional & Isolated \\
\hline
\end{tabular}

Compiled by the authors according to $[1,2,27]$.

periphery they are minimal. In this case, three mechanisms of spatial diffusion can be distinguished $[2,4$, 20] (Fig. 2):

- Contagious (areal, neighborhood-based) mechanism, which suggests the infection of people according to the neighborhood model or classic infection (Fig. 2a): the disease spreads uniformly in all directions from the source of infection, for example, from Moscow to Moscow oblast due to the mobility between home and work, between home and summer cottages, etc.;

-Cascading (hierarchical) mechanism, which suggests the primary infection in the largest agglomerations stemming from innovators who have visited other countries; the disease spreads down the hierarchy of cities (Fig. 2b);

-Network (chain) mechanism, which combines the first two models and suggests the spread of the disease along transport networks (Fig. 2c); in our case, airports, air communications, and sea ports; i.e., the infection is first concentrated in transport hubs. ${ }^{8}$

The contagious (contact) model is predominantly valid at microlevels (within urban communities), while the hierarchical and network models are more applicable at the macrolevels (regions and countries).

\footnotetext{
${ }^{8}$ Confined spaces with a large number of potential carriers (aircraft, buses, ships, etc.) contribute to the rapid spread of the virus.
}

\section{METHODOLOGY AND ITS LIMITATIONS APPLICABLE TO THE ANALYSIS OF THE SPREAD OF DISEASES}

To apply the model, we assumed that the curve in Fig. $1 \mathrm{~b}$ can be described by a parabola's equation, and then, transforming formula (2) into a nondifferential form, we obtain the following expression?

$$
\begin{gathered}
\Delta F(t)=p \bar{F}+(b \bar{F}-p) F(t)-b F(t)^{2} \\
=A_{1}+A_{2} F(t)+A_{3} F(t)^{2}+\varepsilon(t),
\end{gathered}
$$

where $\Delta F(t)$ is the number of new infections per capita at time $t$ and $\varepsilon(e)$ is the residual. In this case, it is easy to find the main parameters of the quadratic equation: the inflection point (extremum $\alpha$ in Fig. 1) and the maximum number of infected people ( $\bar{F}$ in Fig. 1$)$. Nevertheless, modeling itself is possible only after reaching the first stage (the emergence of imitators), and its accuracy becomes sufficient to make reliable forecasts only after reaching the inflection point (extremum of the parabola).

The classic model of the spread of infectious diseases, SIR, in contrast to the one that we described, takes into account not only infectious individuals but also other distribution-related components: susceptible and recovered $[22,29]$. The SIER model also considers exposed (potentially susceptible, latent) patients and the SEIRD model additionally takes into account

\footnotetext{
${ }^{9}$ Also, a more accurate method based on an estimate of the maximum likelihood can be used for modeling.
} 

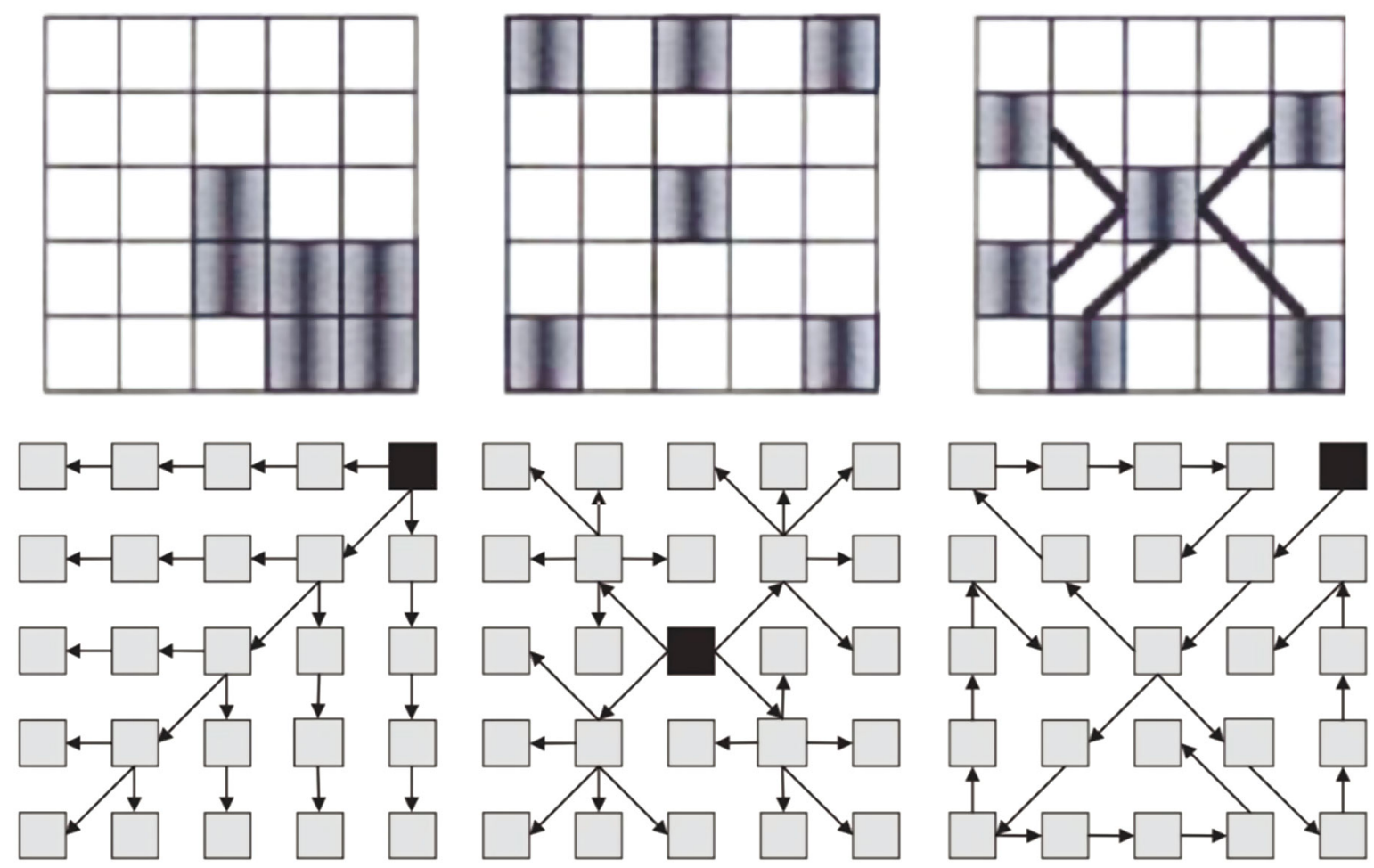

$2 \longrightarrow 3$

Fig. 2. Mechanisms of spatial distribution of coronavirus: (a) contagious model, (b) cascade model, (c) network model. 1, area; 2 , area-source of infection; 3 , direction of spread of disease. Source: [4, 5].

dead patients. Thus, these models make it possible to simulate the most important parameter, the mortality rate, and estimate the burden on the health system. They are not perfect and can underestimate the peak of the disease and overestimate its duration [19, 23]. The contagiousness of the virus could be underestimated [24]. One of the difficulties in using epidemiological models is related to the need to determine the potential number of exposed people and the contact coefficients in society, in hospitals, etc. Due to the lack of high-quality data, these parameters are often defined based on previous epidemics. In this case, modeling concerns the real number of infected patients, not the statistically confirmed one.

Any model is always a simplified reflection of only a part of the factors affecting the process. The medical component is rather successfully modeled by the corresponding epidemiological models. The specification of the model of the diffusion of innovations (3) proposed by the authors can serve the purpose of forecasting only with limitations, since it depends just on the previous rate and the number of those infected. These values are highly volatile, ${ }^{10}$ and the differences

${ }^{10} \mathrm{C}$. Crozier, Forecasting s-curves is hard: https://constancecrozier.com/2020/04/16/forecasting-s-curves-is-hard/. Accessed May 11, 2020. between small numbers in the first stages may be completely random. Other factors, including government actions, are assumed to be unchanged. However, it is obvious that, for example, prolonging the self-isolation regime or imposing a state of emergency can drastically reduce the scale and rate of infection. On their own, measures and their implementation can vary significantly across Russian regions. They depend on the control and enforcement procedures, position of businesses, technical capabilities regarding remote work, informational background, changes in public attitude, etc. However, the model may still be applicable for the geographical analysis of confirmed cases of the disease and observation of deviations as a result of anti-epidemic measures. ${ }^{11}$

Diffusion models are based on the description of social processes, and the number of confirmed cases reflects the latter, rather than solely being a result of biological phenomena. The key factor is interpersonal contacts and communication, and the spread of the disease depends on the informational background (infodemia) [12] and other socioeconomic factors:

\footnotetext{
${ }^{11}$ The SEIR model was also successfully used to model the diffusion of new technologies [32]; i.e., this is a case of mutual scientific enrichment.
} 
Table 2. Assumptions and limitations of application of diffusion of innovations model to the COVID-19 epidemic

\begin{tabular}{|c|c|}
\hline Assumptions & Limitations \\
\hline $\begin{array}{l}\text { Statistics reflect the spread of the innovation } \\
\text { accurately, consistently, and without time lags }\end{array}$ & $\begin{array}{l}\text { The ratio of actual infection cases (able to transmit the virus further) } \\
\text { and confirmed cases (using which we make model estimates) may } \\
\text { differ for several reasons: } \\
\text { - the lack of universal testing; therefore, the potential number } \\
\text { of infected can be significantly greater }{ }^{1} \text {; } \\
\text { - delay in the diagnosis, visit to the doctor, and reflection } \\
\text { in statistics [10]; } \\
\text { - unreliable existing tests [10], high proportion of false results; } \\
\text { - low availability of tests in the early stages }{ }^{2} \text {; } \\
\text { - different ways of organizing testing in terms of the scale, obliga- } \\
\text { tion, and duration }{ }^{3} \text {; } \\
\text { - different methods for identifying those infected }{ }^{4}\end{array}$ \\
\hline Diffusion begins around the same time everywhere & $\begin{array}{l}\text { In cities and regions of Russia, the coronavirus starts spreading } \\
\text { at different times }\end{array}$ \\
\hline Diffusion reaches approximately even saturation & $\begin{array}{l}\text { Proportions of the maximum number of confirmed cases in all cities } \\
\text { and regions are different }\end{array}$ \\
\hline The distribution shape is close to the logistic curve & $\begin{array}{l}\text { It is not typical of all cities and regions, as it depends on actions } \\
\text { of authorities, community structure, etc. }\end{array}$ \\
\hline $\begin{array}{l}\text { Binary process of adopting the innovation } \\
\text { (adopted or not adopted) }\end{array}$ & $\begin{array}{l}\text { The patient may recover, may not show symptoms, the disease may } \\
\text { not be confirmed }\end{array}$ \\
\hline
\end{tabular}

${ }^{1}$ The first antibody tests in the United States and Italy showed that most carriers did not seek help and were not tested, since the disease was mild.

2 As of mid-April 2020, this limitation in Russia has been overcome [10]; however, regional imbalances are still possible, especially taking into account the uneven representation of private laboratories.

${ }^{3}$ Different regions may simultaneously apply different approaches: testing only those hospitalized with suspicious symptoms, all those who have contacted them, risk groups, everyone, or random testing. Approaches are rapidly changing as the number of cases increases, tests become more available, etc. In particular, on April 8, Russia allowed testing in private laboratories. Even with a similar number of tests per capita, different approaches will yield different results. However, when analyzing Russian regions, we can assume similar requirements, at least in state medical institutions.

${ }^{4}$ Since April 8, 2020, the methodology for confirming the diagnosis has changed. According to the recommendation of the Ministry of Health of Russia, not only positive tests but also clinical symptoms were sufficient to confirm the infection.

population structure, advances in medicine, availability of testing, government regulation, etc.

Applying the diffusion model, it is necessary to take into account a number of limitations when interpreting the results (Table 2). The mismatch between real cases of infection and those confirmed by statistics is especially important, since in fact, in the data of Rospotrebnadzor and the World Health Organization, we observe underestimated and delayed statistics. Moreover, there are reasons to believe that the extent of these distortions varies between the phases of the epidemic, from country-to-country, from region-toregion, etc., depending on the state of medicine, availability of tests, general public health, etc. However, in our opinion, this number is proportional in regions to the real number of those infected with a certain lag (equal, as will be shown later, to approximately two weeks), and as the number of tests increases, these discrepancies will fade.

Due to the lack of more reliable statistics, we assume that modeling concerns only the most severe forms of the disease, which led the person to turn to specialists and take tests; i.e., latent forms are not taken into account. At the same time, the scale of testing and the manifestation of latent forms of the disease are interrelated with the geographical factors of the spread of the epidemic (including the city-village dichotomy). In other words, the confirmed incidence is a reflection of these processes. There are reasons to believe that the correlation between the confirmed incidence and the real rate is rather high at the regional level in the later stages, when random factors and testing issues play a lesser role. ${ }^{12}$

In contrast to epidemiological models, we assume the symmetry of the infection rates after the inflection point, which, for example, is not typical for mortality

\footnotetext{
${ }^{12}$ More than 5.4 million laboratory tests for COVID-19 were carried out in Russia as of May 11, 2020, which can be considered a fairly high coverage of the population (https://rospotrebnadzor.ru/about/info/news/). The question of causal relationships between the confirmed morbidity and the number of tests is discussed in more detail in [10].
} 
from COVID-19 13 (the actual number of deaths decreases rapidly after the inflection point). In accordance with the diffusion model of innovations, in contrast, the downward wave of infections in the regions may be more extended (Fig. 1c); i.e., attenuation can take a longer time than during the rising wave. At the same time, we model only the first active part of the epidemic with a large number of new cases. It is obvious that individual outbreaks of the disease will continue to be recorded for a long time in the absence of vaccination of the population. In addition, second and further waves of the disease are possible.

To overcome these and other limitations, multifactor models can be used that take into account the advances made in medicine, incidence, testing, and other factors as control variables. However, such models, in the conditions of the rapid spread of the disease, do not actually allow taking into account the daily change in factors. Most indicators in Russian statistics lag by one or two years and do not have a monthly or quarterly breakdown even by region, not to mention municipalities. Therefore, we are forced to use the least squares method for a specific period of the spread of the disease in the regions of Russia, making the assumption that the factors themselves (independent variables) have not changed since the time they were reflected in the statistics and do not significantly distort the intra-annual dynamics. ${ }^{14}$

Partially, the choice of the regional level of analysis was determined by the available statistics, although this yields generalized results for modeling a phenomenon that spreads through the close contact between people. At the same time, this kind of modeling is possible only at the regional level, sufficient to identify geographical patterns of diffusion. For example, the intracity level is characterized by mainly microgeographic and random factors related to the location of hospitals, nursing homes, crowded places, etc. Of course, the authors understand the role of the subjective factor; however, it is also most significant at the micro level.

In order to identify factors that influenced the spread of infection, in our study we used the following model [1]:

$$
\begin{gathered}
\ln \Delta F_{i, t}=\text { const } \\
+\alpha \ln F_{i, t-1}+\beta \ln \bar{F}_{i}\left(f n_{i, j}\right)+\varepsilon(t),
\end{gathered}
$$

where $\Delta F$ is the number of new infections per capita per day; $i$ is a Russian region; $t$ is the number of days; $F_{(t-1)}$ is the number of carriers per capita on the previous day; and $\bar{F} n$ is the maximum potential number

\footnotetext{
${ }^{13}$ Carl T. Bergstrom: https://twitter.com/CT_Bergstrom/status/1250304069119275009. Accessed May 11, 2020.

14 Unfortunately, this is not true for most indicators, since in Russia as a whole there are strong seasonal dynamics in morbidity, mortality, etc.
}

of infected patients, which depends on $n$ factors in period $j$ :

-basic geographical charateristics of area: population density, concentration in one city, density of the transport network, distance to the center of the outbreak, etc.;

- characteristics of the regional community: proportion of innovators, income, education, intensity of interaction within the community and with other communities (tourists), anti-contagion actions, etc.;

- characteristics of the spread of the disease: the number of days from the first infection, the total number of people infected in the region, the susceptibility of the population to the disease (age, general health, medical infrastructure), etc.

As a respiratory disease, COVID-19 spreads most rapidly through personal contact. To account for this, we need to understand how many people in the region reside in territories with certain population densities, which partially overcomes the disadvantage of an excessively generalized level of analysis. Other things being equal, a higher density leads to a greater number of contact between people and a higher rate of the spread of the disease.

The hypotheses and all variables are described in Table 3.

Each stage is characterized by its own combination of factors [1,2]. At the initial stage, the position relative to the source of innovations (according to the neighborhood-based model) and transport centers (the network diffusion model) and the proportion of potential innovators may be more important. In accordance with the hierarchical model of diffusion, large cities and densely populated centers with large airports, where the proportion of community members and migrants frequently traveling abroad is higher, are most affected. Most of the variance remains unexplained due to random factors. At the stage of rapid spread, a key role can be played by the structure of the community and connections between the innovators and the majority. Infection encompasses regions near the foci of the disease, and accordingly, the proportion of temporary migrants is significant here. Poorer regions with high overall morbidity are generally can be more susceptible to the spread of COVID-19. We used crime rates and unofficial employment as an inverse indicator of the trust of community members to each other, and, accordingly, the development of small and medium-sized businesses (attraction points for residents) as an indirect indicator of potential internal ties [3]. At the stage after the inflection point, the role of random factors decreases and the number of new infections in remote regions grows. The earlier the first case is confirmed in the region the lower the infection rate at this stage.

Several strongly correlating variables were chosen to describe each factor (and hypothesis); therefore, the authors tested the indicators one at a time, choos- 
Table 3. Key factors and indicators. Values are given for last available year

\begin{tabular}{|c|c|c|c|c|}
\hline Group of factors & Factor & $\begin{array}{l}\text { Hypothetical } \\
\text { effect }\end{array}$ & Designation & Description \\
\hline \multirow[t]{5}{*}{ Spatial characteristics } & $\begin{array}{l}\text { Density of potential } \\
\text { human interaction }\end{array}$ & $+/-$ & Pop & $\begin{array}{l}\text { Proportion of residents of the region living } \\
\text { in municipalities with population density } \\
\text { in a given interval, } \% \text { (Table } 4 \text { ) }\end{array}$ \\
\hline & $\begin{array}{l}\text { Population } \\
\text { concentration }\end{array}$ & + & $U r b$ & Proportion of urban residents, $\%$ \\
\hline & \multirow[t]{2}{*}{$\begin{array}{l}\text { Proximity to major } \\
\text { sources of potential } \\
\text { interaction }\end{array}$} & \multirow[t]{2}{*}{+} & Demo & $\begin{array}{l}\text { Demogeographic potential of the region } \\
\text { (population of other regions divided by } \\
\text { squared distance to them), people } / \mathrm{km}^{2}\end{array}$ \\
\hline & & & $E G P$ & $\begin{array}{l}\text { Potential of the economic and geographi- } \\
\text { cal location, proximity to large markets in } \\
\text { Russia and the world [6] }\end{array}$ \\
\hline & $\begin{array}{l}\text { Transport network } \\
\text { density }\end{array}$ & + & Aero & $\begin{array}{l}\text { Passenger traffic of region's airports }{ }^{1}, \\
\text { mln people }\end{array}$ \\
\hline \multirow{9}{*}{$\begin{array}{l}\text { Characteristics of a } \\
\text { regional community }\end{array}$} & \multirow[t]{2}{*}{ Standards of living } & \multirow[t]{2}{*}{+} & Poverty & Poverty rate, $\%$ \\
\hline & & & Income Min & $\begin{array}{l}\text { Per capita income in relation to the cost } \\
\text { of living, } \%\end{array}$ \\
\hline & \multirow[t]{2}{*}{$\begin{array}{l}\text { Proportion } \\
\text { of innovators }\end{array}$} & \multirow[t]{2}{*}{+} & UrbHEd & $\begin{array}{l}\text { Proportion of urban workers with higher } \\
\text { education [31] }\end{array}$ \\
\hline & & & Online & $\begin{array}{l}\text { Proportion of the population using the } \\
\text { Internet to order goods and services, } \%\end{array}$ \\
\hline & \multirow{2}{*}{$\begin{array}{l}\text { Intensity of internal } \\
\text { interaction related } \\
\text { to the level of trust } \\
\text { in the community }\end{array}$} & \multirow[t]{2}{*}{+} & Crime & Number of crimes per capita [3] \\
\hline & & & Unform & $\begin{array}{l}\text { Proportion of unofficial employment } \\
\text { in total employment, } \%\end{array}$ \\
\hline & \multirow[t]{3}{*}{$\begin{array}{l}\text { Intensity of external } \\
\text { interactions }\end{array}$} & \multirow[t]{3}{*}{+} & Tur2 & $\begin{array}{l}\text { Number of residents who toured to China, } \\
\text { Italy, France, and Germany, per mln } \\
\text { inhabitants }\end{array}$ \\
\hline & & & RusTour & $\begin{array}{l}\text { Number of Russian citizens in shared } \\
\text { accommodation facilities, per mln } \\
\text { inhabitants of the region }\end{array}$ \\
\hline & & & Migr & Migration growth \\
\hline \multirow[t]{5}{*}{$\begin{array}{l}\text { Disease characteristics } \\
\text { and community } \\
\text { vulnerability }\end{array}$} & \multirow{3}{*}{$\begin{array}{l}\text { Susceptibility to diseases } \\
\text { and opportunities } \\
\text { for detection } \\
\text { (confirmation) }\end{array}$} & \multirow[t]{3}{*}{+} & Desgov & $\begin{array}{l}\text { Average annual morbidity reported by } \\
\text { state medical institutions, thousand } \\
\text { people }\end{array}$ \\
\hline & & & Medexp & $\begin{array}{l}\text { Budget expenditures on healthcare per } \\
\text { capita, thousand rubles/person }\end{array}$ \\
\hline & & & Medpers & $\begin{array}{l}\text { Number of medical staff, per thousand } \\
\text { people }\end{array}$ \\
\hline & $\begin{array}{l}\text { Initial incidence } \\
\text { of coronavirus }\end{array}$ & + & $\operatorname{Coron}(t-1)$ & $\begin{array}{l}\text { The number of carriers (cumulative } \\
\text { number of confirmed cases) per capita in } \\
\text { the region a day ago }\left(F_{(t-I)} \text { in formula } 4\right)\end{array}$ \\
\hline & $\begin{array}{l}\text { Coronavirus spreading } \\
\text { time }\end{array}$ & $\begin{array}{c}+/- \\
\text { depending on } \\
\text { the stage }\end{array}$ & Day & $\begin{array}{l}\text { Number of days since the first confirmed } \\
\text { case }\end{array}$ \\
\hline
\end{tabular}

${ }^{1}$ http://www.avia-adv.ru/placement/airports/passenger-traffic.htm. Source: Rosstat data, unless otherwise indicated. 


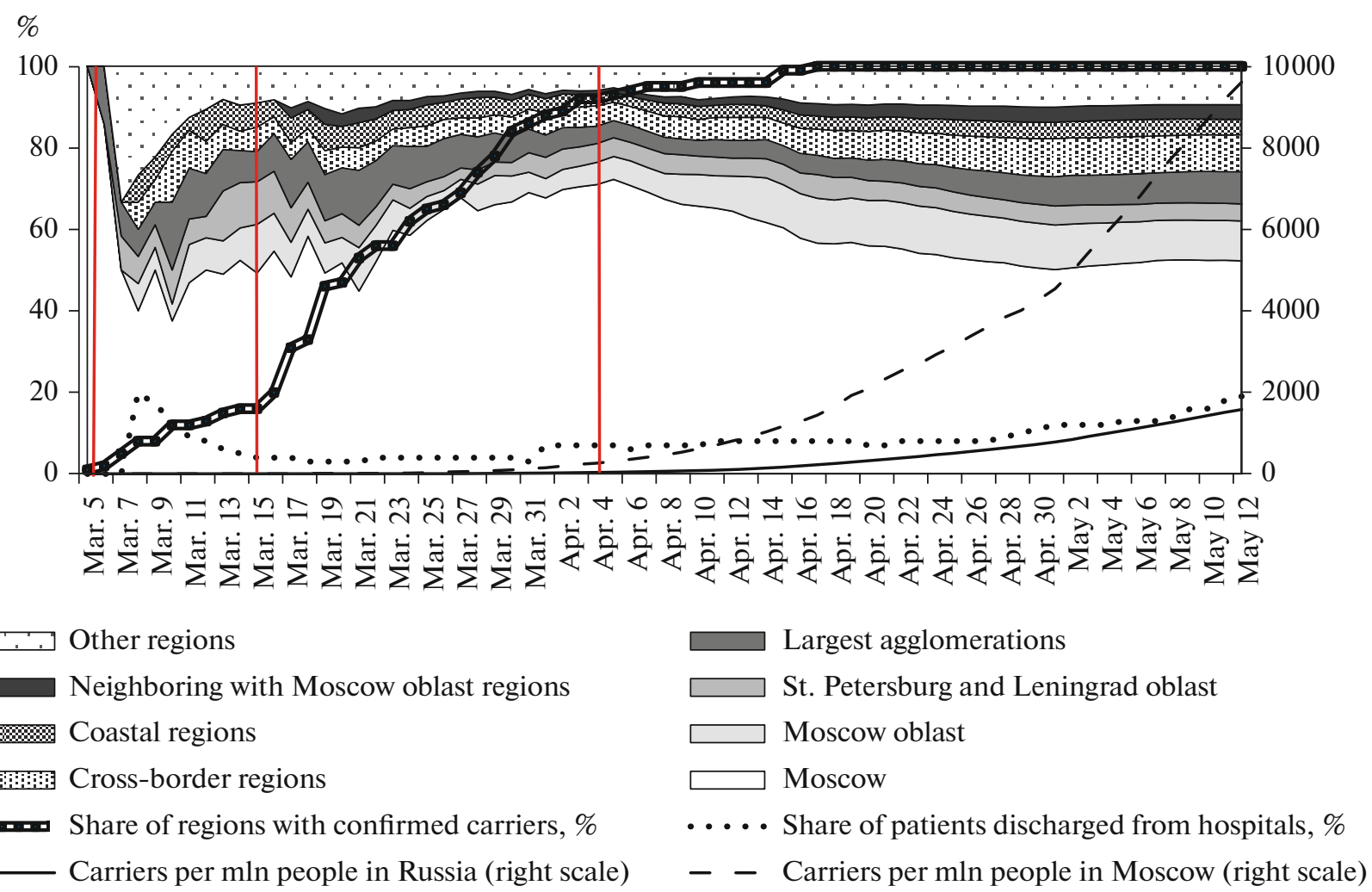

Fig. 3. Geography and dynamics of confirmed COVID-19 cases in Russia. Percentage shows share of different groups of regions in cumulative number of confirmed COVID-19 cases.

ing the model with the best characteristics: maximum $R^{2}$, minimum Schwarz information criterion, and significance $(*)$ of a larger number of variables. Independent variables are taken with a time lag, which partially solves a possible endogenous problem. Nevertheless, in the regressions, we used only spatial data without taking into account the change in variables over time, therefore it is more correct to speak not about the factors determining the spread of the disease, but about the characteristics of regions where the incidence was higher.

\section{RESULTS AND DISCUSSION}

\section{Geography and Dynamics of Confirmed COVID-19 Cases in Russia}

Considering the dynamics of the spread of the disease in the Russian regions (Figs. 3 and 4), we can trace the classic stages of spatial diffusion $[2,20]$.

The first stage of origin before March 7, 2020: more than $80 \%$ of the first recorded infected patients (innovators) were concentrated near the source of the infection (Chinese workers in Zabaykalsky krai) and in the center of the city hierarchy: Italian workers and Russian tourists coming from Italy to Moscow. The rest were randomly shared between transport hubs and near the foreign source of infection. The source of infection (Moscow) and innovators (foreign workers) may have been weakly related to the other regional communities. It was possible to stop the disease under a strict quarantine and forced hospitalization of the arrivals [13]. The Russian authorities evacuated Russian citizens from the Chinese province of Hubei, the one most affected by the epidemic. All visitors from the foci of the disease were quarantined. The government temporarily suspended the issuance of work visas to Chinese citizens and limited air traffic with China and the crossing of the Russian-Mongolian border. However, these measures turned out to be insufficiently effective and belated, ${ }^{15}$ since not everyone who arrived from abroad followed the quarantine regulations.

The second stage of emergence and slow spread lasting from March 7 to March 15, 2020 was marked by the first confirmed infected cases inside the country due to the neighborhood effect: imitators. ${ }^{16}$ From this point on, stopping the spread of the disease became problematic. About $80 \%$ of the carriers were concen-

\footnotetext{
${ }^{15}$ At least compared to the measures to combat the outbreak of the cholera epidemic in the south of the former Soviet Union in 1970 [13].

${ }^{16}$ Rospotrebnadzor reported three coronavirus infection cases in Russia: https://tass.ru/obschestvo/7983369. Accessed May 11, 2020.
} 


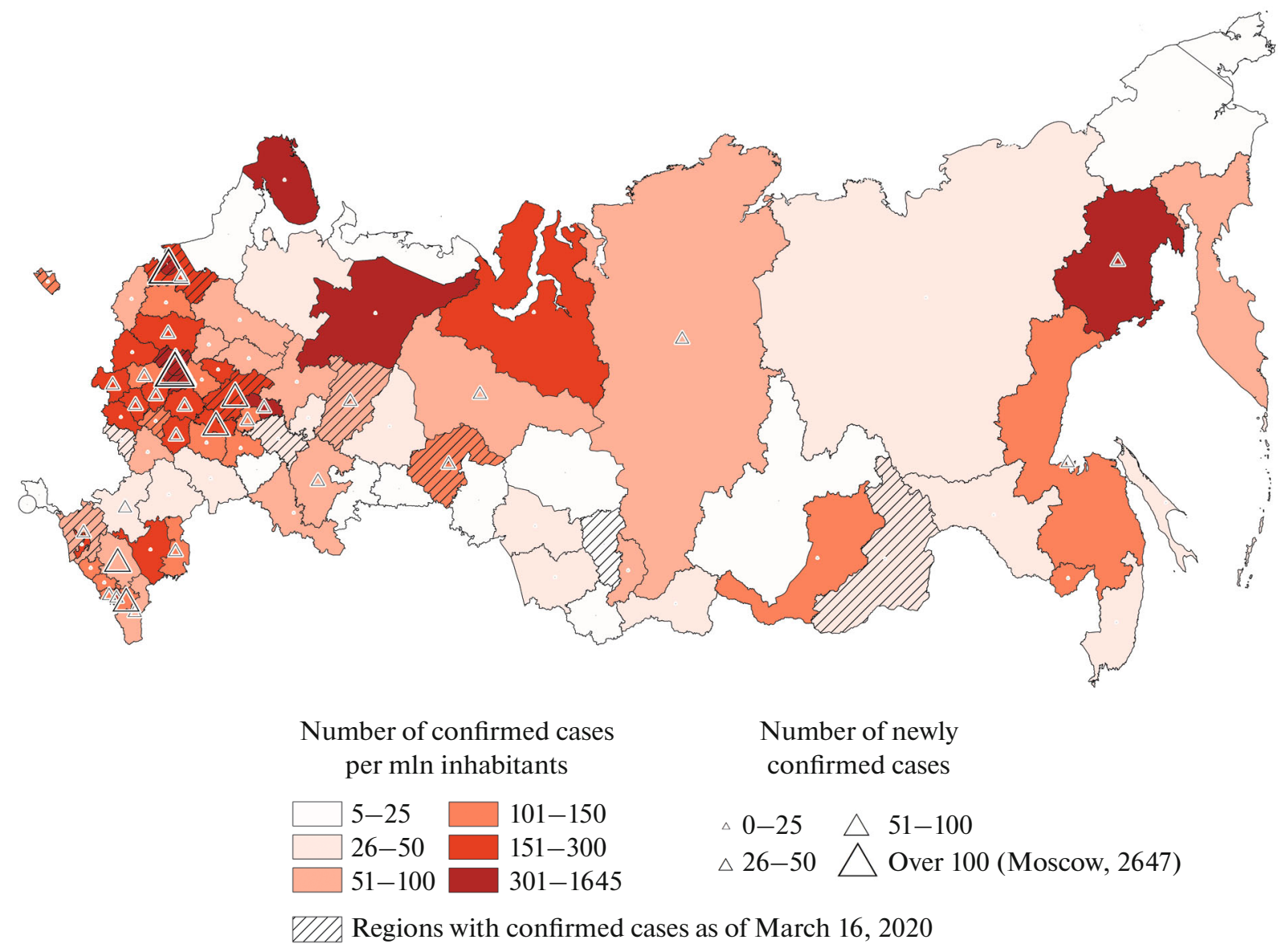

Fig. 4. Confirmed COVID-19 cases in regions of Russia as of April 18, 2020.

trated at the source of primary infection (Moscow), centers of the city hierarchy (St. Petersburg, Nizhny Novgorod oblast, Tatarstan, Perm krai), and large air hubs (Krasnodar krai, Kaliningrad oblast), where the first infected patients arrived from abroad. As a result of the neighborhood effect (imitation), there were cases of infection outside the largest agglomerations (in Moscow and Leningrad oblasts) and the first infections among those coming from abroad to other regions (Lipetsk and Kemerovo oblasts). There were still no cases of deceased patients. This was the most important moment for the authorities to take action, since there was still an opportunity to toughen the quarantine, hospitalize new arrivals, and introduce the self-isolation regime. On March 16, the Ministry of Education and Science of Russia recommended Russian universities to switch to distance learning. Air traffic with the countries of the European Union was restricted. The Prime Minister of Russia gave instructions to prepare the set of measures to deal with the coronavirus. Medical buildings for the infectious center started to be constructed in Moscow. As of March 21, 2020, events with more than 50 participants were banned in Moscow and all schools were closed.
March 16 marked the stage of the rapid spread of the coronavirus infection: the number of new confirmed infections grew exponentially, from 67 to 97 people per day. The next day, the number of regions with confirmed cases increased from 14 to 26; and on March 19, to 39 regions. From April 6, the concentration in Moscow began to decline due to the rapid increase in the number of carriers in the periphery of the Moscow and St. Petersburg agglomerations (the neighborhood effect): Moscow oblast, Leningrad oblast, and Tula oblast, as well as in the largest agglomerations: Nizhny Novgorod, Yekaterinburg, Krasnodar, Kazan, Chelyabinsk, Perm, Samara, Voronezh, and Novosibirsk. New outbreaks emerged outside the large agglomerations; they were related to the constant air traffic (network model of diffusion), migrants, shift workers, and the high density inside the cities in Komi, Dagestan, Crimea, and Saratov oblast, as well as the Khanty-Mansi and Yamalo-Nenets autonomous okrugs. On the same day, the first death of a patient with coronavirus was officially reported. ${ }^{17}$

\footnotetext{
${ }^{17}$ The first death from the coronavirus in Russia confirmed: https://lenta.ru/news/2020/03/19/infect/. Accessed May 11, 2020.
} 
Diffusion spread throughout the country, to 80 out of the 85 regions: until mid-April, only the most remote regions with low transport accessibility and low population density remained unaffected: the Nenets Autonomous Okrug, Altai Republic, Republic of Tyva, and the Chukotka Autonomous Okrug; by April 17, cases of the disease were confirmed in all regions; and by the end of April, deaths were observed in most regions. At that stage, it was impossible to stop the spread of the disease. On March 31, the authorities in 26 regions, including the largest ones (Moscow, St. Petersburg, Moscow oblast, Nizhny Novgorod oblast, Sverdlovsk oblast, Rostov oblast, and Tatarstan), introduced the self-isolation regime, which was supposed to slow the spread and allow the healthcare system to cope with the influx of patients and minimize the number of additional deaths.

We note that, at the exponential stage, Murmansk oblast and Komi Republic had high infection rates (see Fig. 4): in the northern regions, the population is concentrated in several cities, which are characterized by a high proportion of migrants and active interaction with other cities and countries. Temporary workers come from Moscow, for example, to PAO NOVATEK construction sites in Murmansk, while local residents go on vacations to the south.

Presumably, in early May, the spread of the disease is before the stage of accumulation near the inflection point. There has been widespread distribution at a decreasing rate in the largest centers, the proportion of infected regions without large agglomerations is growing, and the percentage of people who recovered is increasing (see Fig. 3). At the same time, the number of new infections is minimal in the largest cities (with the exception of the two capitals and Nizhny Novgorod) and the peripheral remote regions. In the case of a steady decrease in the number of new cases within the next two weeks, the first restrictions have been lifted [11]. On May 7, 2020, the maximum number of newly confirmed cases of the disease in Moscow was recorded, after which it decreased. The inflection point in Russia was passed on May 11 (11656 new cases).

The saturation stage lied ahead: decay of the spread, absence of large numbers of new infections in multiple regions, and an exponential increase in the proportion of survivors. It is possible to lift almost all restrictions. Unfortunately, unlike the diffusion of technologies, COVID-19 will not disappear completely until a vaccine is found and universal vaccination is carried out. Therefore, the number of new cases began to rise again from September 2020, reaching a new pick of 10888 new cases on October 5.

\section{Modeling the Dynamics of Confirmed Cases of COVID-19 in Russia}

To construct the model of the spread of COVID-19 in Russia using formula (3), we distinguished several periods (Fig. 5).

The first period is the time before March 21, 2020, when the number of confirmed infected cases decreased slightly immediately after the introduction of additional antiepidemic measures in Moscow. According to the calculations for that date, in accordance with the assumptions of the model, the number of confirmed cases would have not exceed 1500, and the end of the active stage of the epidemic would have been in mid-April (Fig. 5a). Apparently, this period was characterized by multiple random factors and low testing coverage, which could have easily misled the authorities and scientists about the future extent and danger of the disease. It is possible that if the strictest quarantine measures [13] with respect to visitors from abroad had been introduced immediately throughout the country in March, the described scenario could have been realized. However, this was not possible politically with such few infected cases. Even today some members of Russian society consider the measures taken to be an excessive restriction of their freedom. The scenario contradicts the experience of China, where quarantine measures were stricter but the epidemic lasted more than three months. Although according to the assumptions of the spatial diffusion model (see Fig. 1c), the swiftness and scale of the spread in Russia could have decreased as the disease was spreading from the source of the outbreak (China) due to the growing experience in containment, the health system being more prepared, etc. This scenario was not implemented and the number of confirmed cases in the regions began to grow exponentially.

On March 29, the self-isolation regime was introduced in Moscow and many regions, and the population of the largest cities minimized their mobility ${ }^{18}$ and social contacts. Until April 15, 2020, the number of new cases was increasing exponentially (Fig. 5b); with such dynamics, without the actions of the authorities, the total number of confirmed cases could have approached half a mln by the end of June. But the rate of the spread was reduced, and according to the data of April 27, 2020, we can see the trend deviating from the exponential, which began two weeks after the introduction of the self-isolation regime (Fig. 5c). In our opinion, this was due to the introduced restrictions and the proper response of citizens. The new scenario assumed about 150000 confirmed cases across the country and the expected end of the active stage of the epidemic by mid-June. Since in the calculations the majority of those infected are actually Moscow resi-

\footnotetext{
${ }^{18}$ Self-Isolation Index, Yandex: https://yandex.ru/ maps/covid19/isolation? $11=41.775580 \% 2 \mathrm{C} 54.894027 \& z=3$. Accessed May 11, 2020.
} 

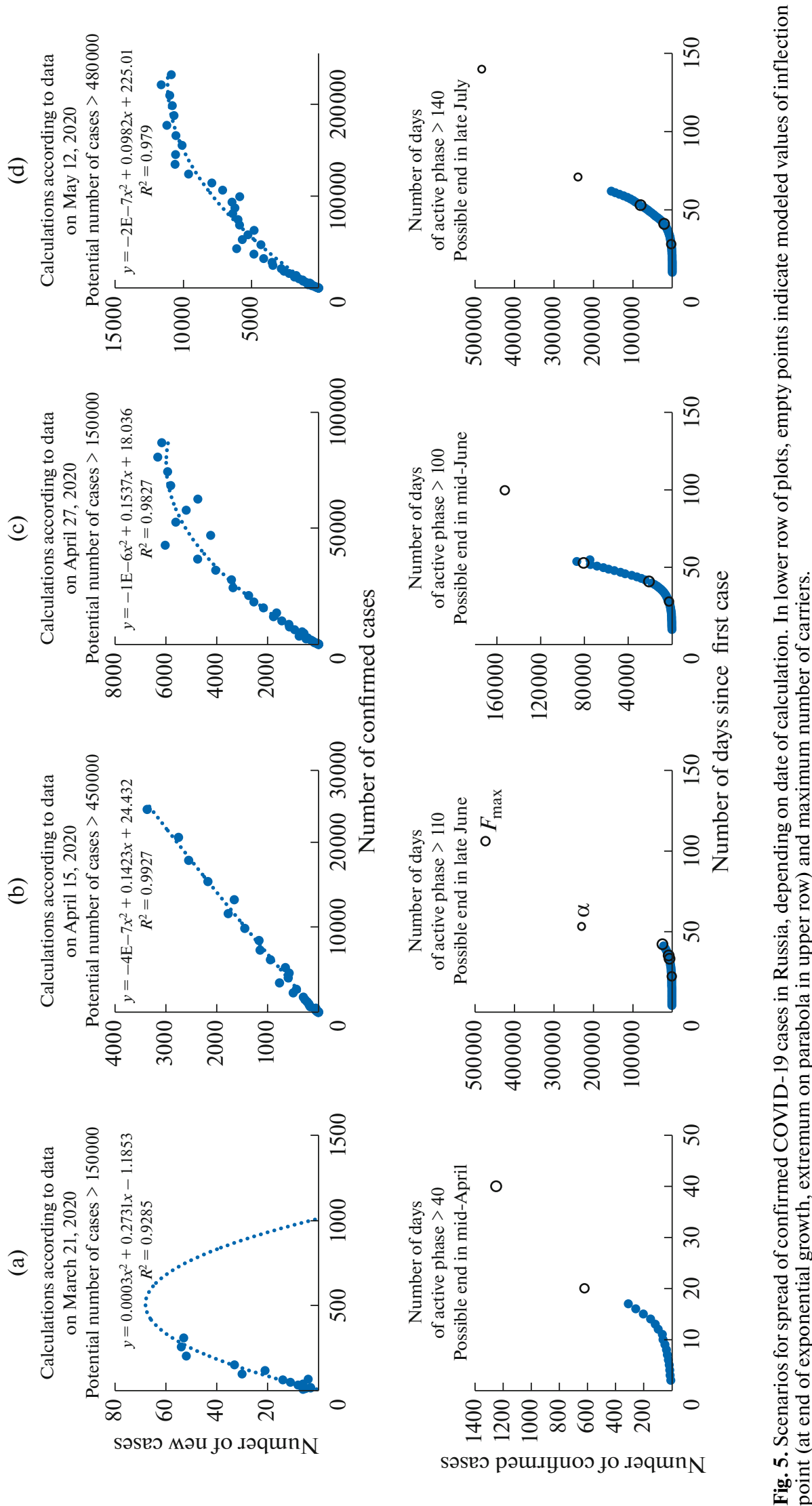
dents, it should be said that these assumptions are more applicable to the capital and large metropolitan areas, while in other regions the epidemic may continue.

However, this optimistic scenario was not realized. In the first days of May, the proportion of infections in Moscow began to grow again (see Fig. 3), with actual stabilization in half of the regions for a week. Perhaps this is partially due to the introduction of checkpoints in Moscow, when there were queues in the subway in mid-April. Changes in the infection rates and the dynamics of confirmed cases in statistics are separated by about a two-week lag. Extending the general testing and the initiated antibody testing could also affect the dynamics. A negative course of events might lead to the need to expand the regime of self-isolation and extend it until July, which in turn would have a devastating effect on small and medium-sized businesses and the entire economy in Russia [7]. Fortunately, the number of new cases in Russia began to decline slowly at the end of May, mainly due to a decrease in Moscow.

As can be clearly seen from the plots (see Fig. 5), the diffusion models constructed using real data, rather poorly predict the development of events in the early stages of the spread of the disease before the inflection point, since they do not take into account the actions of the authorities and the public response. In addition, the smaller the number of cases the higher the stochastic component. The estimated evidencebased scenarios will be significantly differ for individual regions (see Fig. 1c), and for the majority it is not applicable at all due to the prevalence of random factors and differences in conditions that we sought to account for in the next section of this paper.

Although the number of new cases in Russia began to decline at the end of May, and many restrictions were lifted, the rate of these changes was significantly lower than anticipated in the model. And the graph in Figure 1a is asymmetric. Taking into account the second wave of the epidemic, the proposed model is not applicable for forecasting due to significant distortions in statistics, unpredictability of anti-epidemic measures and the reaction of residents.

\section{Factors of the Spread of COVID-19 in Russian Regions}

In order to identify the most significant regional characteristics affecting the rate of spread of the disease, we first tested the hypothesis on the high significance of the population density (Table 4), taking into account the control variables: the cumulative number of carriers per capita in the region the previous day $\left(\right.$ Corona $\left._{t-1}\right)$ and the number of days since the first confirmed case (Day) [28]. In the first period, before the introduction of restrictions on movement (as of March 15, 2020), the only positive significant factor was the proportion of residents living in municipalities with the population density above 3000 people $/ \mathrm{km}^{2}$ (Pop 10000). These are mostly the highly densely populated areas of the country's largest agglomerations (for example, the central regions of Moscow) and transport hubs, as described above.

In the second period, two weeks after the introduction of restrictions (as of April 13, 2020), the significant positive factors included the saturation level achieved (Corona $\left.a_{t-1}\right)$ and the number of days since the beginning of the epidemic (Day), that is, the number of previously infected, due to the neighborhood effect and exponential growth. At the same time, the epidemic did not reach the least densely populated municipalities; therefore, the spread of the disease was lower in regions where the proportion of residents living in municipalities with the population density of less than 8 people $/ \mathrm{km}^{2}$ was high (Pop8). In the period of exponential growth, the process covered the whole country, and in the regions where it started earlier, the rate of the spread decreased (negative coefficient in variable Day). In the last period, on approaching the inflection point, the number of cases in the most densely populated areas again increased (Pop 10000), where the density of confirmed carriers per capita was high $\left(\right.$ Corona $\left._{t-1}\right)$. This was due to the growing number of new cases in Moscow, Moscow oblast, and Nizhny Novgorod oblast, which may be explained by the expanding testing ${ }^{19}$.

It can be clearly seen from the increasing $R^{2}$ that the stochastic process, almost inexplicable at the initial stage ( $R^{2}$ is slightly above zero), was becoming increasingly deterministic ( $R^{2}$ is above 0.6$)$, except for the last period when the proportion of unexplained dispersion again increased (see Tables 4, 5).

Then we tested all the hypotheses given in Table 3, alternately testing indicators for each of our favorite factors, and selected models with the best characteristics, where all variables are significant (Table 5).

At the first stage of diffusion, until March 15, one of the most significant factors is the total annual morbidity of the population. If the total morbidity in the region (Desgov) in previous year was $1 \%$ higher than in other regions, the number of newly confirmed cases of COVID-19 per mln inhabitants was $0.042 \%$ more. At the same time, it is not clear what effect prevails here, the low public health [8] and susceptibility to infections or the proper development of the healthcare system and testing that is able to detect a new infection. As expected, the positive significant factor at the ini-

\footnotetext{
${ }^{19}$ There is another assumption. In some regions in May the same values of the daily number of new ones were repeated, which is statistically unlikely. Number of demographers and statisticians believe that data may be inaccurate and require additional verification. According to their allegations, regional authorities and local businesses can be interested in premature quarantine removal, and accordingly - an underestimation of the number of new cases. However, the proof of this hypothesis was not included in the goal of our article.
} 
Table 4. Results estimating effect of population density in municipalities on spread of COVID-19 in Russian regions

The dependent variable is the number of newly confirmed COVID-19 cases per capita in a Russian region on the given date. The method of least squares was used. Robust standard errors. A total of 83 regions covered.

\begin{tabular}{|c|c|c|c|c|c|c|c|c|}
\hline Variable/Date & as of Mar & 15,2020 & as of $A p$ & 13,2020 & as of $A p$ & 27,2020 & as of $\mathrm{Mc}$ & 12,2020 \\
\hline model specification & 1a & $1 b$ & $3 a$ & $3 b$ & $4 a$ & $4 b$ & $5 \mathrm{a}$ & $5 b$ \\
\hline Const & -0.12 & $0.14^{* * *}$ & 0.76 & 0.51 & $3.47^{*}$ & 2.5 & -3.99 & $-1.42 * * *$ \\
\hline$l \_$Corona $(t-1)$ & 0.029 & -0.0075 & $0.30^{* *}$ & $0.29 * *$ & $0.84 * * *$ & $0.88^{* * *}$ & $0.73 * * *$ & $0.73 * * *$ \\
\hline l_Day & -0.052 & -0.042 & 0.32 & $0.39 * *$ & $-1.2 * * *$ & $-1.2 * *$ & 0.41 & \\
\hline l_Pop1 & 0.034 & & -0.12 & & $-0.12^{*}$ & & -0.004 & \\
\hline l_Pop8 & 0.0033 & & $-0.18^{* *}$ & $-0.19 * *$ & -0.07 & & 0.07 & \\
\hline l_Pop100 & 0.035 & & $-0.20^{*}$ & $-0.19 * *$ & -0.13 & & 0.10 & \\
\hline l_Pop500 & 0.020 & & $-0.20^{* *}$ & $-0.20 * *$ & -0.07 & & 0.07 & \\
\hline l_Pop 1000 & 0.013 & & 0.076 & & 0.01 & & 0.05 & \\
\hline l_Pop3000 & 0.028 & & -0.025 & & -0.04 & & 0.11 & \\
\hline l_Pop10000 & $0.090 * *$ & $0.072^{* *}$ & 0.027 & & 0.06 & $0.11^{*}$ & $0.16^{* * *}$ & $0.12 * * *$ \\
\hline$R^{2}$ & 0.09 & 0.07 & 0.31 & 0.29 & 0.66 & 0.63 & 0.58 & 0.51 \\
\hline Adjusted $R^{2}$ & -0.02 & 0.04 & 0.22 & 0.24 & 0.61 & 0.62 & 0.52 & 0.50 \\
\hline Schwarz criterion & 78.8 & 54.2 & 270 & 255 & 198 & 177 & 207 & 188 \\
\hline
\end{tabular}

1. The proportion of region's population in municipalities where the population density is within the given interval $(\%)$ : Pop $1,<1$ people/km²; Pop 8, 1-8; Pop 100, 8-100; Pop 500, 100-500; Pop 1000, 500-1000; Pop3000, 1000-3000; Pop 10 000, 3000.

2 . Asterisks indicate significance ( $p$-value): ${ }^{* * *} 0.01 ; * * 0.05 ; * 0.1$.

tial stage is the higher proportion of innovators, those visiting countries-foci of the disease (Tur2) every year and having technological skills (Online). The share of innovators is higher in the largest agglomerations, northern mining centers and near major Russian and foreign markets $(E G P)[6]$. Due to the epidemic outbreak in China (the largest market in the world) and in Moscow, the favorable economic and geographical position might contribut to the primary infection of the public. The rate of the spread is lower in regions where the level of trust in society is lower due to high crime rates (Crime) and, accordingly, where the intensity of interaction within the community, the density of small businesses, and the interpersonal communication are lower [3].

All other things being equal, none of the models had significant characteristics of transport accessibility (Aero), although it was assumed that large airports could be sources of infection. Most likely, this actually was the case; however, the presence and the proximity of densely populated (Pop 10000) and large center, as measured by various indicators of geographical location (EGP, Demo), were more significant. In other words, it is not the presence of the airport that is important but the size of the center in which it is located, because infection rates were affected by the high density of social contacts, while air traffic was gradually restricted.
The significance of the presence (Urb) and proximity of large cities (Demo) in the region was higher at the exponential stage of growth. This was the neighborhood effect: the infection spread from large centers (Moscow) to neighboring regions due to the return of temporary labor migrants and migration to summer cottages, which is clearly seen in Fig. 4. At the stage of exponential growth (as of April 13, 2020), despite the introduced self-isolation measures, the number of new infections per capita was $0.14 \%$ higher in regions where the proportion of Russian citizens accommodated in hotels was $1 \%$ higher (Rostur), that is, in regions with a high intensity of business trips from other regions. In regions with the higher annual overall morbidity of the population (Desgov) and higher health care costs (Medexp), the number of new cases was also higher. Such regions have a higher density of laboratories, better quality of equipment for detecting the disease, potentially lower public health, and a higher proportion of older people. In regions where the crime rate (Crime) is higher and, accordingly, the density of small business and social interaction is lower, the penetration rate of COVID-19 is lower. The number of new cases is $2.2 \%$ higher in regions where the poverty level (Poverty) is $1 \%$ higher, as the infection has spread to poor regions, and the poor population cannot fully adapt: stop working or switch to remote working, move to a summer house, order goods online, etc. 
Table 5. Results of estimating the factors of spread of COVID-19 in Russian regions

The dependent variable is the number of newly confirmed COVID-19 cases per capita in a Russian region at the given date. The method of least squares was used. Robust standard errors. A total of 83 regions covered.

\begin{tabular}{|c|c|c|c|c|c|}
\hline Factor & Variable & $\begin{array}{c}\text { as of March 15, } \\
2020\end{array}$ & $\begin{array}{c}\text { as of April 13, } \\
2020\end{array}$ & $\begin{array}{c}\text { as of April 27, } \\
2020\end{array}$ & $\begin{array}{l}\text { as of May 12, } \\
2020\end{array}$ \\
\hline Model specification & & 1 & 2 & 3 & 4 \\
\hline \multirow[t]{2}{*}{ Population density } & I_Pop 10000 & $0.06^{* *}$ & & & \\
\hline & l_Pop8 & & $-0.20^{*}$ & & \\
\hline Urban concentration & l_Urb & & $1.3^{* *}$ & & \\
\hline \multirow{2}{*}{$\begin{array}{l}\text { Proximity and size of neigh- } \\
\text { boring regions }\end{array}$} & l_EGP & $0.04 * *$ & & $0.09 *$ & \\
\hline & l_Demo & & $0.34 * * *$ & & $0.36^{* * *}$ \\
\hline \multirow[t]{2}{*}{ Proportion of innovators } & l_Online & $0.14^{*}$ & & & \\
\hline & l_UrbHEd & & $0.28 * *$ & & $2.0^{* * *}$ \\
\hline \multirow{2}{*}{$\begin{array}{l}\text { Standard of living in the } \\
\text { region }\end{array}$} & I_Poverty & & $2.3^{* * *}$ & & $0.88^{* *}$ \\
\hline & l_IncomeMin & & & $1.02 * *$ & \\
\hline \multirow[t]{2}{*}{ Internal interaction, trust } & l_Crime & $-0.24 * *$ & $-1.0^{* * *}$ & & \\
\hline & l_Unform & & & & $0.8^{* *}$ \\
\hline \multirow[t]{3}{*}{ External interaction } & l_Tur2 & $0.06^{* *}$ & & $0.14^{* * *}$ & \\
\hline & l_Migr & $0.15^{*}$ & & & \\
\hline & l_Rustur & & $0.66^{* * *}$ & & \\
\hline \multirow[t]{3}{*}{ Susceptibility to diseases } & l_Desgov & $0.043^{* *}$ & $0.20^{* * *}$ & $-0.19^{* * *}$ & \\
\hline & l_Medexp & & $1.5^{* * *}$ & & \\
\hline & l_Medpers & & & $-1.24^{* * *}$ & \\
\hline Epidemic duration & l_Day & $-0.12^{* *}$ & & & \\
\hline Constant & Const & $-0.88^{* *}$ & $-20^{* * *}$ & $10.9^{* * *}$ & $10.9^{* * *}$ \\
\hline \multirow[t]{3}{*}{ Model quality criteria } & $R^{2}$ & 0.27 & 0.49 & 0.73 & 0.38 \\
\hline & Adjusted $R^{2}$ & 0.2 & 0.43 & 0.70 & 0.34 \\
\hline & Schwarz criterion & 56.2 & 245.4 & 168.4 & 221.6 \\
\hline
\end{tabular}

Asterisks indicate significance ( $p$-value): ***0.01; ** $0.05 ; * 0.1$.

At the late exponential stage (according to the data on April 27, 2020), the influence of some factors has changed to the opposite direction. For example, in regions with a higher overall incidence rate (Desgov) and medical staff availability (Medpers), the spread rate has become lower. Apparently, diffusion in large cities has slowed, and the disease has spread to regions with less developed health care systems. In the northern regions with high per capita incomes (Income_Min) and a high concentration of the population in certain municipalities, the number of new cases is greater.

At the last stage, diffusion has spread to the northern large urban regions with a high proportion of residents with higher education (UrbHEd) and to the least developed regions with high levels of unofficial employment (Unform) and poverty (Poverty).

\section{CONCLUSIONS AND DIRECTIONS FOR FUTURE RESEARCH}

According to this study, the diffusion model of innovations with a number of assumptions and limitations can be applicable for the spatial analysis of the spread of confirmed COVID-19 cases. We considered only severe statistically confirmed cases. The real extent of the spread is unknown due to the supposedly two-week lag between contracting the disease and diagnosis, the lack of universal antibody testing, ${ }^{20}$ and other limitations described in detail in the methodology. 
The diffusion of COVID-19, in the early stages discussed in the article, was mainly determined by the situation in Moscow; thus, it should be noted that the scenarios considered by the authors characterized the situation in the capital, where the end of the active phase of the epidemic was expected by early July. In fact, increase in the number of contacts as a result of lifting quarantine measures, did not lead to a possible jump in the incidence rate in Moscow, where, according to the data as of July 10, 2020, only 637 new cases were recorded (a close value at the beginning of the epidemic is typical for April 7, 2020). Unfortunately, the number of new cases is declining slowly in other regions with large agglomerations: St. Petersburg, Nizhny Novgorod, Omsk, Sverdlovsk, Novosibirsk, Voronezh regions, as well as in the centers of labor migration: Tyumen region, Khanty-Mansiysk and Yamalo-Nenets autonomous regions. At the same time, as a number of factors affect the spread and confirmation of the disease in the Russian regions, the disease continue spreading in the peripheral and semiperipheral regions: Magadan, Amur, Sakhalin, Kurgan regions. New cases will be observed until the formation of collective immunity and / or the full vaccination of the population.

The first confirmed carriers of coronavirus came from abroad and were initially concentrated in the largest metropolitan areas, maritime centers, and regions neighboring China; however, the spread of the disease could not be contained. The experience of countries such as the Republic of Korea, Taiwan, Japan, and Singapore shows the importance of massive, prompt, and high-quality testing and tracing of all contacts of those infected at the initial stage. Such an approach, when properly implemented, can contain the spread of the epidemic without large-scale quarantine measures. However, at the initial stage, such measures were not sufficiently effective in Russia. By mid-April, the first cases were confirmed in all regions of the country. Therefore, the self-isolation regime that allows reducing the burden on the healthcare system during the period of the exponential growth of infections became necessary. However, its effectiveness was confirmed in statistics only after two weeks as a deviation from the exponential trend. At the same time, Sweden (at the initial stage) did not introduce harsh restrictive measures; instead, their authorities only recommended reducing social and other contacts. However, in this case, the level of confidence of citizens in the government and their ability and willingness to follow the recommendations are important. In Russia, with a low level of general trust in most regions [9], such a policy did not work before the introduction of prohibitive measures. This is clearly seen in the dynamics of the self-isolation index of Yan-

\footnotetext{
${ }^{20}$ The domestic antibody testing system was registered on April 10, 2020, and medical personnel began to be tested on April 15 [10]. It is known that the majority of those infected are asymptomatic.
}

dex, which shows how light the road traffic is. This index rose only on March 19 after the introduction of the self-isolation regime.

Among other regional characteristics determining the spread of the virus in the Russian regions, we note the high population density in individual municipalities, as an indirect indicator of social contacts in transport, in residential buildings, etc., proximity to the largest metropolitan areas as foci of infection, high proportion of the most active and frequently traveling part of the population, and the intensity of ties within the community and with other countries and regions. The rate of exponential spread is higher in regions with a high susceptibility of the population to diseases, which confirms the corresponding statements on the importance of the region's health capital. At the same time, the factors differ significantly at different stages of the spread. In the initial stages, the effect of random events is high, which reduces the ability to correctly model processes.

We only considered confirmed infection cases. Without the data on the excess mortality in MarchApril over the mortality in these months on average in previous years, we cannot talk about the most significant effects of the epidemic due to statistical and other distortions in the current period [17, 21]. For example, many who died from COVID-19 had chronic illnesses. There are some data on regions in Italy and the UK, ${ }^{21}$ where a significant (up to 60\%) excess of the total mortality in March-April was observed. At the same time, the correct and final data on mortality in the European Union will not be available for at least another two months and that for Russia not until the end of the year. According to the preliminary data for Moscow, mortality in April 2020 is $20 \%$ higher than the average for the previous decade: 11846 deaths compared to $9866 .^{22}$ It can be expected that the additional mortality rate from all causes in Russia in comparison with previous years will also increase. For example, mortality from heat waves and smoke in the European part of the country in 2010 was previously underestimated, while according to the results of the year, the additional mortality amounted to more than 55000 cases, including 11000 cases, or $60 \%$ increase compared to previous years, in Moscow [14]. This can also be the subject of further research.

The socioeconomic consequences of the COVID-19 epidemic in 2020 in Russia still have to be estimated; however, the increase in morbidity, mortality, and the introduction of quarantine measures are resulting in higher unemployment and lower economic growth worldwide. The most negative impact will be on the

\footnotetext{
${ }^{21}$ EuroMOMO: https://euromomo.eu/. Accessed May 11, 2020.

${ }^{22}$ Open Data Portal of the Government of Moscow: https:// data.mos.ru/opendata/7704111479-dinamika-registratsii-aktovgrajdanskogo-sostoyaniya/row/1035521177? pageNumber $=13$ $\&$ versionNumber $=3 \&$ releaseNumber $=42$. Accessed May 11 , 2020 .
} 
business sector [7]. Although in Moscow most of those employed can switch to working remotely and in industrial areas with continuous manufacturing, people can and are obliged to work, in regions that depend on tourism and on small businesses in retail trade and household services, the consequences may be more severe. Moreover, in large agglomerations, the opportunities for adaptation of both the population and business are high due to the availability of various forms of remote work and a high degree of Internet penetration, as well as its use for ordering goods and services. The level of digitalization of the economy will dramatically increase. Estimates for the opportunities and risks of the digital economy were discussed earlier [30]. This is another prospective subject for research, which can clarify which regions and cities may experience more noticeable social changes in the event that the self-isolation regime is extended.

\section{ACKNOWLEDGMENTS}

The authors thank V.M. Kidyaeva, N.K. Kurichev, T.N. Mikhailova, I.S. Kashnitsky, the anonymous reviewers, and other colleagues for their discussion and valuable comments.

\section{FUNDING}

This study was supported as part of the 2020 RANEPA state task and Program 5-100 of Kant Baltic Federal University on Increasing Competitiveness.

\section{CONFLICT OF INTEREST}

The authors declare that they have no conflict of interest.

\section{REFERENCES}

1. Baburin, V.L. and Zemtsov, S.P., Regions-innovators and innovative periphery of Russia. Study of ICT-products diffusion, Reg. Issled., 2014, no. 3, pp. 27-37.

2. Baburin, V.L. and Zemtsov, S.P., Innovatsionnyi potentsial regionov Rossii (Innovative Potential of Russian Regions), Moscow: Universitetskaya Kniga, 2017.

3. Barinova, V.A., Zemtsov, S.P., and Tsareva, Yu.V., Entrepreneurship and institutions: Does the relationship exist at the regional level in Russia?, Vopr. Ekon., 2018, vol. 6, pp. 92-116.

https://doi.org/10.32609/0042-8736-2018-6-92-116

4. Blanutsa, V.I., Postal innovations in pre-Soviet Siberia, Geogr. Prirod. Resur., 2012, no. 4, pp. 30-39.

5. Blanutsa, V.I., Spatial diffusion of innovations: the scope of uncertainty and the network model, Reg. Issled., 2015, no. 3, pp. 4-12.

6. Zemtsov, S.P. and Baburin, V.L., Assessing the potential of economic-geographical position for Russian regions, Ekon. Reg., 2016, vol. 12, no. 1, pp. 117-138.

7. Zemtsov, S. and Tsareva, Yu., Development trends of small and medium-sized enterprises amid pandemic- induced crisis, Monit. Ekon. Situatsii Ross. Tendentsii Vyzovy Sots.-Ekon. Razvit., 2020, no. 9 (111), pp. 16-26.

8. Kaneva, M.A., The impact of public health capital on the economic growth in Russian regions, Reg.: Ekon. Sotsiol., 2019, no. 1, pp. 47-70.

9. Kosarev, V., Pavlov, P., and Kaukin, A., Social capital as a factor in the economic growth of Russian regions, Ekon. Polit., 2019, vol. 14, no. 5, pp. 144-149.

10. Nazarov, V. and Sisigina, N., Comparative analysis of approaches to testing for Covid-19 in Russia and foreign countries, Monit. Ekon. Situatsii Ross. Tendentsii Vyzovy Sots.-Ekon. Razvit., 2020, no. 9 (111), pp. $22-38$.

11. Nazarov, V.S., Sisigina, N.N., and Avksent'ev, N.A., Approaches to elimination of restrictions accepted to prevention of distribution of new coronavirus infection, Monit. Ekon. Situatsii Ross. Tendentsii Vyzovy Sots.Ekon. Razvit., 2020, no. 11 (113), pp. 21-31.

12. Petrov, N., Arkhipova, A., Spiridonov, V., and Peigin, B., Infodemia: existing approaches to the analysis of panic, phobias, rumors, and fakes during epidemics and proposals to prevent them, Monit. Ekon. Situatsii Ross. Tendentsii Vyzovy Sots.-Ekon. Razvit., 2020, no. 8 (110), pp. 70-78.

13. Popov, V.F., The cholera epidemic in the USSR in 1970, BIOprep. Profil., Diagn., Lech., 2011, no. 2 (42), pp. 36-38.

14. Revich, B.A., Heatwaves, air quality, and mortality in the European part of Russia in the summer of 2010: preliminary assessment results, Ekol. Chel., 2011, no. 7, pp. 3-9.

15. Bass, F.M., A new product growth for model consumer durables, Manage. Sci., 1969, vol. 15, no. 5, pp. 215227.

16. Bertrand, J.T., Diffusion of innovations and HIV/AIDS, J. Health Commun., 2004, vol. 9, suppl. 1, pp. 113-121.

17. Chen, N., Zhou, M., Dong, X., Qu, J., Gong, F., Han, Y., Qiu, Y., Wang, J., Liu, Y., Wei, Y., Xia, J., Yu, T., Zhang, X., and Zhang, L., Epidemiological and clinical characteristics of 99 cases of 2019 novel coronavirus pneumonia in Wuhan, China: a descriptive study, Lancet Infect. Dis., 2020, vol. 10223, no. 395, pp. 507513.

https://doi.org/10.1016/S0140-6736(20)30211-7

18. Comin, D.A., Dmitriev, M., and Rossi-Hansberg, E., The Spatial Diffusion of Technology, Cambridge, Ma: Natl. Bureau Econ. Res., 2012.

19. Grant, A., Dynamics of COVID-19 epidemics: SEIR models underestimate peak infection rates and overestimate epidemic duration, medRxiv, 2020.

20. Hagerstrand, T., Innovation Diffusion as a Spatial Process, Chicago, IL: Univ. Chicago Press, 1968.

21. Hauser, A., Counotte, M., Margossian, C., Konstantinoudis, G., Low, N., Althaus, C., and Riou, J., Estimation of SARS-CoV-2 mortality during the early stages of an epidemic: a modeling study in Hubei, China and Northern Italy, medRxiv, 2020. https://doi.org/10.1101/2020.03.04.20031104

22. Kucharski, A.J., Russell, T.W., Diamond, C., Liu, Y., Edmunds, J., Funk, S., et al., Early dynamics of transmission and control of COVID-19: a mathematical 
modeling study, Lancet Infect. Dis., 2020, vol. 20, no. 5, pp. 553-558.

23. Korolev, I., Identification and estimation of the SEIRD epidemic model for COVID-19, 2020. https://ssrn.com/abstract=3569367. https://doi.org/10.2139/ssrn.3569367

24. Liu, Y., Gayle, A.A., Wilder-Smith, A., and Rocklöv, J., The reproductive number of COVID-19 is higher compared to SARS coronavirus, J. Travel Med., 2020, vol. 27, no. 2, art. ID taaa021.

25. New-Product Diffusion Models, Mahajan V., Muller E., and Wind Y., Eds., New York: Springer-Verlag, 2000, vol. 11.

26. Meade, N. and Islam, T., Modeling and forecasting the diffusion of innovation-A 25-year review, Int. J. Forecasting, 2006, vol. 22, no. 3, pp. 519-545.

27. Rogers, E.M., Diffusion of Innovations, New York: Simon and Schuster, 2010, 4th ed.

28. Shet, A., Ray, D., Malavige, N., Santosham, M., and Bar-Zeev, N., Differential COVID-19-attributable mortality and BCG vaccine use in countries. https://www.medrxiv.org/content/10.1101/2020.04.01. 20049478v1.full.pdf?fbclid=IwAR38RiJFdGqpsqZ-
PHHT2FD1zmRDyDo3zLN-OrTRUv9r2e11-VIMMLmYh2CE.

29. Wu, J.T., Leung, K., and Leung, G.M., Nowcasting and forecasting the potential domestic and international spread of the 2019-nCoV outbreak originating in Wuhan, China: a modeling study, Lancet Infect. Dis., 2020, vol. 395, no. 10225, pp. 689-697.

30. Zemtsov, S., Barinova, V., and Semenova, R., The risks of digitalization and the adaptation of regional labor markets in Russia, Foresight STI Gov., 2019, vol. 13, no. 2, pp. 84-96.

https://doi.org/10.17323/2500-2597.2019.2.84.96

31. Zemtsov, S. and Kotsemir, M., An assessment of regional innovation system efficiency in Russia: the application of the DEA approach, Scientometrics, 2019, vol. 120 , no. 2 , pp. $375-404$. https://doi.org/10.1007/s11192-019-03130-y

32. Zhao, D. Sun, J., Tan, Y., Wu, J., and Dou, Y., An extended SEIR model considering homepage effect for the information propagation of online social networks, Phys. $A$ (Amsterdam), 2018, vol. 512, pp. 1019-1031.

Translated by K. Lazarev 